\title{
The Brothers Čapek at the Gate: R.U.R. and The Insect Play
}

Ondřej Pilný

The intention of Hilton Edwards and Micheál mac Liammóir to introduce major works of contemporary world drama to Irish audiences is clearly reflected in the impressive list of productions by the Gate Theatre under their artistic leadership (see Luke 93-104). This chapter examines two important but hitherto largely neglected stagings of famous European dramas, R.U.R. and The Insect Play, which it attempts to reconstruct insofar as the available documentary evidence allows. In the process, it discusses the complicated textual history of the English versions produced by the Gate and finally compares their reception with that of the first productions in Czechoslovakia, teasing out the points of convergence and elucidating the differences brought about by the respective theatrical and political contexts.

\footnotetext{
O. Pilný $(\bowtie)$

Charles University, Prague, Czech Republic e-mail: ondrej.pilny@ff.cuni.cz

(C) The Author(s) 2021

O. Pilný et al. (eds.), Cultural Convergence, https://doi.org/10.1007/978-3-030-57562-5_6
} 


\section{R.U.R.}

R.U.R.: Rossum's Universal Robots by Karel Čapek received its first professional production at the National Theatre in Prague on 25 January 1921. The play pictures the revolt of artificial human beings devised to perform manual labour instead of humans, whose name was derived by the author's brother Josef from the Czech word 'robota', i.e. 'heavy toil' or 'hard labour'. It was the first major achievement for Ćapek, who was soon to become a celebrated fiction writer, playwright, journalist and a vocal public intellectual in Czechoslovakia. His international reputation, somewhat regrettably, has come to rest largely on this early play, particularly as it has been recognized in retrospect as a seminal forebear of science fiction. The enormous success of R.U.R. in Prague (Fig. 6.1), where the production played until 1927 for a total of 63 performances, ${ }^{1}$ and where spectators initially had to queue for tickets from 6 a.m. or buy them underhand (Černý 105), triggered multiple translations that were produced to acclaim across Europe from Aachen to Belgrade, in New York and in Tokyo over three years alone (Černý 93). The achievement is all the more remarkable given that Czech theatre was not really on the radar internationally at the time; as it happens, the foremost Czech theatre historian František Cerný has argued that Čapek's R.U.R. in fact represents the first instance of a major Czech author addressing the world, as opposed to the nation, since Comenius (72).

It is hardly surprising that Hilton Edwards and Micheál mac Liammóir decided to stage R.U.R. as early as during the Gate's second season. Both Edwards and mac Liammóir may have seen the first London production directed by Basil Dean at St. Martin's Theatre, which opened on 24 April 1923 and ran for 127 performances (Wearing 224), since, at the time, the former was living in London and the latter had an exhibition of his paintings and drawings there (Fitz-Simon 45, 48). Moreover, as in Czechoslovakia, the play created an extensive debate in the British press as regards its exact meaning and implications. St. Martin's Theatre even hosted a discussion about the work on 21 June 1923 that featured Bernard Shaw and G.K. Chesterton as speakers, to which Čapek sent a response that appeared in The Saturday Review (23 July 1923). ${ }^{2}$ Capek - together with his brother, who was a frequent collaborator - quickly became recognized as a prominent experimental playwright whose work was mostly labelled expressionist in Britain (see Vernon 135-37), notwithstanding his protestations to the contrary. Expressionist - and broadly 


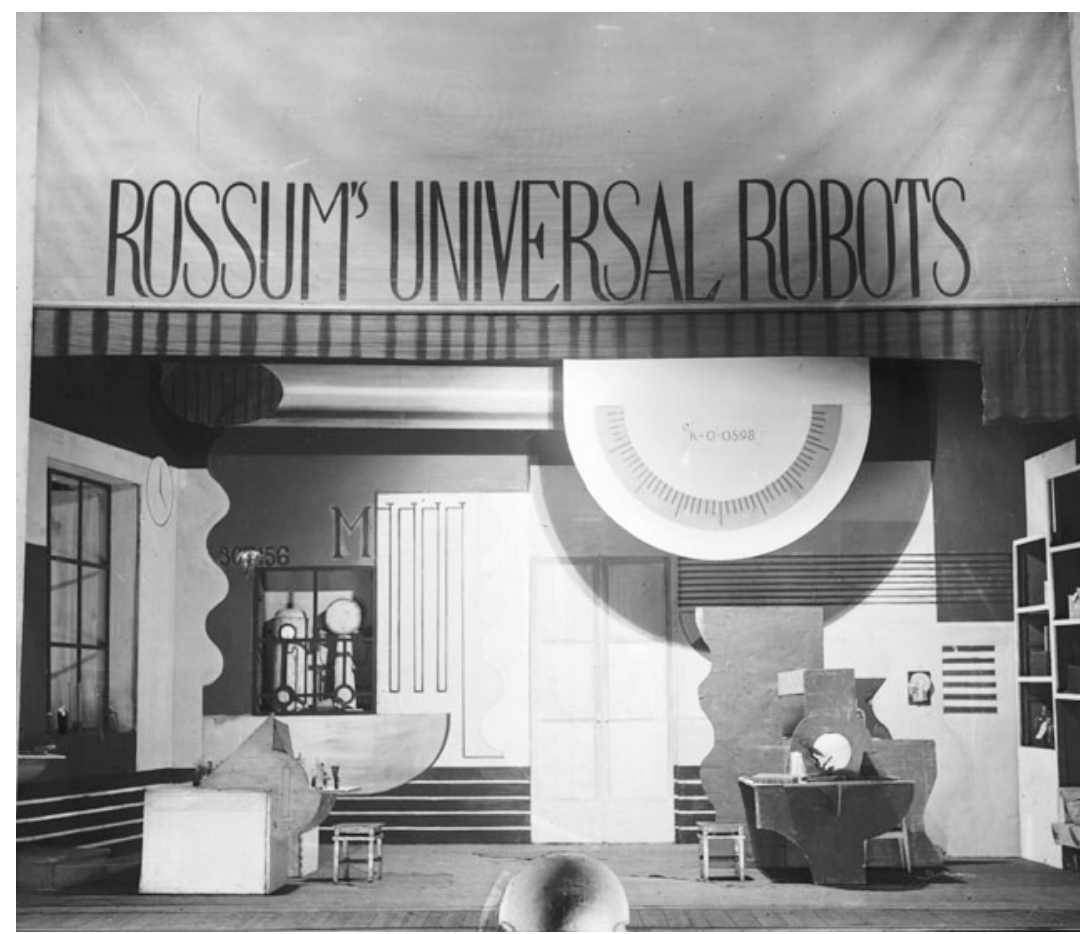

Fig. 6.1 Karel Capek, R.U.R., Act III, National Theatre, Prague, 1921. Set design by Bedřich Feuerstein. Photograph by Karel Váña (Courtesy of the Theatre Department of the National Museum in Prague)

speaking avant-garde - drama was particularly attractive to Edwards and mac Liammóir in the early years of the Gate and became a principal ingredient of its repertoire, particularly whenever it addressed pressing social and political issues through intense emotion. ${ }^{3}$ All in all - and regardless of inevitable flaws that were due to the author's lack of previous theatrical experience ${ }^{4}$ - Čapek's formally innovative, moving play about humanity in jeopardy was ideal material for the Gate's artistic directors. 


\section{Textual History}

Any comparison of the staging and reception of R.U.R. by the Prague National Theatre with the production at the Dublin Gate - or indeed any English-language production until the 1990s - must take into account the fact that the respective audiences saw a staging of a considerably different text. The play was translated into English by Paul Selver, a seminal figure in making modern Czech literature available to Anglophone readers in the 1910s-1940s. Selver has frequently been accused of bowdlerizing the originals, but Robert Philmus has demonstrated that, as regards R.U.R., the accusation is mostly unjust, since the non-correspondences with Capek's original text in the versions of Selver's translation published in the UK and in the US, respectively, are mostly due to it having been adapted for the English stage by Nigel Playfair prior to its appearance in print. ${ }^{5}$ Philmus has also pointed out that Čapek - who spoke English reasonably well - retained Selver as his English translator until the end of his life, and thus must have been content with his work (23). On the other hand, the process of adapting and staging the play in London involved such convolutions that Selver ended up writing a satirical novel on the subject (Philmus 27 n30).

Selver's original translation (which appears not to have survived) was most likely made from a typescript of the play used by the Prague National Theatre for its first production (Philmus 19), and the available evidence - sparse as it may be - indicates that apart from changing the headings of the acts (whereby the original Prelude became Act I, and the original Act III was retitled 'Act IV. Epilogue'), the only major departure from the original consisted in Selver's rendition of the maid Nána's lines in standard English, as opposed to a rural dialect peppered with colloquial turns of phrase. Nána was intended by Čapek to represent the voice of down-to-earth common sense and folk wisdom (see Černý 78), which was reflected by the linguistic contrast with all other characters. This contrast was flouted by Selver, whose forte never was the translation of non-standard varieties of Czech, and eventually led to much of Nána's part being cut by the English adaptor, since when rendered in standard English, many of Nána's observations would have come across as either bland or as self-evident. Further cuts in what remained of the part were often introduced by directors, including Hilton Edwards. What may likewise be regarded as a deficiency is Selver's decision not to translate the name of the creator of the robots and founder of the company: 'Rossum' 
is homophonous with the Czech word for reason, 'rozum', and translators into other languages have mostly taken this into account. ${ }^{6}$

The alterations made by Nigel Playfair were of much greater consequence, however, and came to shape the later production at the Gate as well, since Edwards worked from his adaptation as published in Britain. They included renaming two of the company's managers - Hallemeier turned into Helman and the Consul Busman into Jacob Berman and the Czech diminutive Nána was changed to Emma. Together with Selver's rendition of the General Manager's name, Harry Domin, as Harry Domain, these linguistic shifts toned down the author's universalist intention, since Čapek deliberately based the names of his characters in a range of languages from Latin and Greek to English, German, French and Spanish (see Černý 76). Helena Glory, instead of being the daughter of the President of the company, became the 'Daughter of Professor Glory, of Oxbridge University' (Čapek, J. and K., list of characters), which removed the main reason for the deference of the company's managers to the young woman in Act I. The part of the robot Damon, who is the chairman of the robots' Central Committee, was cut, together with any references to the Committee itself. Most of Damon's lines were given to robot Radius. Radius thus became the sole leader of the robots of the world, and the clear reference in the original to the communist party disappeared. ${ }^{7}$ The detailed outlines of the characters' appearances, as well as the description of the nature of the robots' movements and delivery, along with the costumes recommended by Čapek, were also deleted.

The considerable textual cuts in the English adaptation included the powerful dissection scene in the final act: the last of the humans, Alquist, is made by the robots to search for the secret of their reproduction, without which they are doomed to follow humanity into extinction. As his effort is proving to be in vain, he is ultimately asked to experiment on Damon. Since the robots are biological in their nature, the scene involves an incision made with a knife in a live body and is accompanied with heart-rending screams. The scene was very likely considered too intense for the audience. ${ }^{8}$ Indeed, its disturbing effect was confirmed by the first Prague production: despite being performed behind glass and in silhouette only, the audience was always visibly shocked by the scene, and once a spectator even fainted (Černý 101). The final act in fact suffered the most extensive pruning as a whole, with the first half of Alquist's opening monologue and the second half of his closing speech disappearing altogether. It may be argued, however, that much like the less drastic cuts 
that were made in the dialogues of the closing act, these deletions actually work in favour of the drama, since they by and large remove the more wordy or melodramatic passages.

Finally, flowers have an important symbolic dimension in the original, but this vanished in the English adaptation of the play. At the beginning of Act II, Alquist makes a present of a new species of cyclamen to Helena. In the Czech text, we are told that, as an artificial hybrid, the flower is unable to reproduce. It is analogous to Helena in this respect, as Helena very much wishes to have children but cannot, and to humanity more generally, which has become sterile since it has begun to spurn physical labour. The cyclamen, as well as humanity itself, are repeatedly referred to as 'hluché květy / hluchý květ', i.e. 'barren blossom(s)', which was a Czech idiomatic expression for that which was devoid of purpose (the expression appears in the original as many as ten times; Čapek, K. 2018, $50,56,85)$. All these passages have disappeared in the English version and with them also the 'Ibsenesque' (Philmus 22) symbolism of the flowers. The same applies to virtually all references to human sterility, amounting to several pages of printed text, mostly in Act II; an important similarity between the humans and the robots has thus been removed.?

\section{R.U.R. BY THE GATE}

R.U.R. was first staged by the Gate at the Peacock Theatre in May 1929. Sadly, no record of the production has been preserved in the Gate Theatre Archive; from the press cuttings pertaining to the 1931 revival, it is possible to ascertain only that the role of Domain was played by Micheál mac Liammóir, Hilton Edwards played Alquist, and Helena Glory and the Robotess Helena were both played by Coralie Carmichael. ${ }^{10}$ Apart from that, we know that three of the other roles were acted by Hubert Duncombe ('Suicide'), Joseph Millar ('Degree') and Gearóid Ó Lochlainn. ${ }^{11}$ The significant doubling of the two Helenas was Edwards's decision, as no doubling is indicated in the text and was not introduced in the London production of R.U.R. either. However, Edwards thus intuitively used the same solution as that adopted in the Prague National Theatre production, where the suggestion to couple the two characters came from an actress in rehearsal (Cerný 105). In this way, both productions came to emphasize Čapek's hopeful suggestion that despite its self-induced extermination, humanity will continue to live in the robots. 
Fig. 6.2 Karel Čapek, R.U.R., Gate Theatre, Dublin. Promotion flyer for the 1931 revival.

Gate Theatre Archive, Northwestern University (Copyright of the Edwards - mac Liammóir Estate)

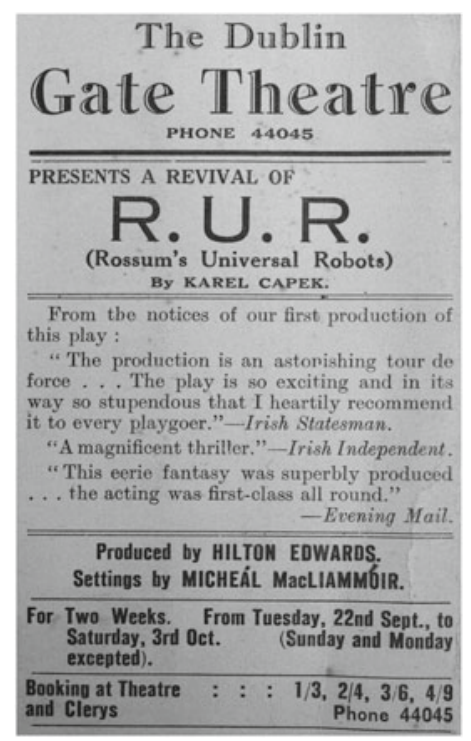

The reception of the Gate's R.U.R. must have been favourable enough to solicit a revival in a relatively short time; this is testified also by the inclusion of several rapturous quotes from reviews in a publicity leaflet issued by the Gate for the 1931 revival ('The Dublin Gate Theatre') (Fig. 6.2). The decision to revive the production may have also had to do with the move of the company from the small Peacock to a larger theatre of their own that had a bigger stage and better equipment, which would have allowed for a more impressive presentation of the scenes involving the siege and the ambush of the humans by the robots in particular.

Archival evidence pertaining to the 1931 production allows for reasonable insight in the work of the director in particular. The text that Edwards used was the 1930 Oxford edition of the play. Given that it was a revival of a recent staging, the extent of his preparation is remarkable. The three copies of the play text preserved in the Gate Theatre Archive (all of the same edition) demonstrate that Edwards first made two series of minor cuts and pencilled in a few basic directions concerning the movement of the characters. Of course, he may have transferred some of his notes from the prompt copy of the 1929 production, but this cannot 
be established with any certainty, since the original prompt copy has not survived. The third volume, inscribed as Prompt Copy, reproduces the same cuts in the text, adds a few more and includes detailed directions concerning movement, as well as the names of the cast in pencil (see Fig. 6.3 for an example).

Generally, Edwards's cuts help to maintain the rhythm and the tempo of the action, a tendency displayed by Čapek himself when revising the text of the first Czech edition. This may also explain why Act IV - which had already been significantly pruned by Nigel Playfair - remained virtually untouched by Edwards. Importantly, however, Edwards added the following lines to be spoken by the robots Helena and Primus in the middle of Alquist's final monologue in Act IV: 'Look Primus. Flowers. / For your hair, Helena. How beautiful you are.' (Čapek, K. 1930, 102)

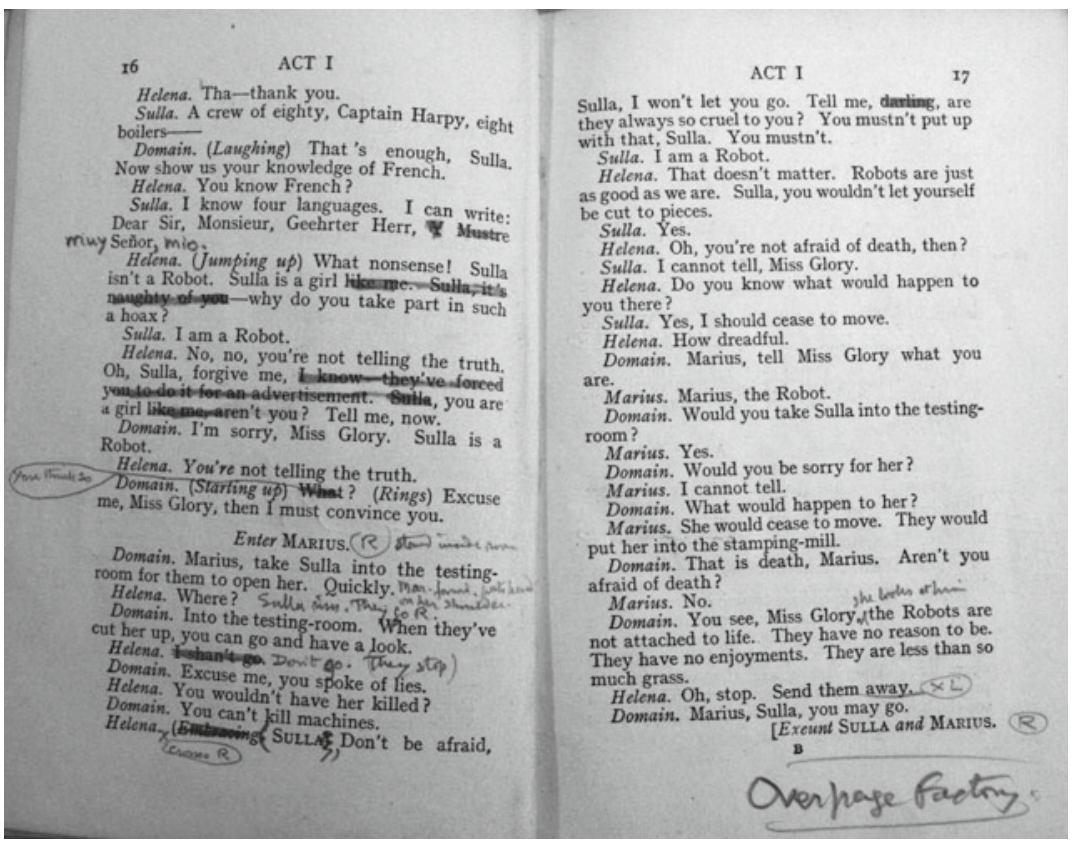

Fig. 6.3 Karel Čapek, R.U.R., Gate Theatre, Dublin. Prompt book for the 1931 revival. Gate Theatre Archive, Northwestern University (Copyright of the Edwards - mac Liammóir Estate) 
The addition demonstrates an intuitive awareness of the symbolic role of flowers discussed above, since the director had no way of knowing how elaborate this feature had been in Čapek's original. ${ }^{12}$ Apart from that, Edwards also altered a few passages in order to make Selver's English sound less formal. The time of action was specified in the printed programme as 'between A.D. 1950-1960'; neither Čapek's original nor the published English version are prefaced with such a note but the fact that the play is set in a future that is not too distant is indicated in the opening act, where the audience are told that old Rossum started

his experiments in 1920 (Čapek, K. 2018, 13) or 1922 (Čapek, J. and K. 5), respectively, i.e. immediately preceding the time of the drama's production in Prague and in London.

The set and costumes were designed by mac Liammóir; no photos or designs seem to have survived but we know that the production used a painted set, as Charles Marford is listed in the programme as the painter. The set design for the opening act featured an ingenious medley of posters in many languages, including Irish' (D.M.), and as so often with Edwards's work, the lighting design was impressive and the direction astute: in a reviewer's description, 'as the drama grows in intensity, the style of the staging and lighting as well as the acting, change' and ' $[\mathrm{t}] \mathrm{he}$ close of the second act - the procession pouring in, of victorious Robots, and the extraordinary dramatic lighting of the final scene are masterpieces of theatrical art' ('A World of Robots'). The music used in the performance consisted of 'selections from De Falla, Debussy, Mendelssohn, etc.' performed by The Gate Theatre Trio directed by Bay Jellett (Dublin Gate Theatre - R.U.R.). The revival of R.U.R. was scheduled to run for two weeks.

\section{RECEPTION}

Edwards's production was praised in all reviews of the opening night's performance, and so was the acting by mac Liammóir, Edwards and Carmichael, and of James Murphy as Radius, whose 'stentorian voice' and 'herculean frame' ('A World of Robots') were highlighted in particular. Admiration was expressed as well for Nancy Beckh, who undertook the role of Emma at 'a few hours' notice' (M.M.) instead of Molly Tapper. In contrast to the production qualities, the assessment of Čapek's play ranged from positive to overwhelmingly negative, and the few observations that were made about its meaning were widely divergent, echoing 
the critical discord that followed both the Prague première and the London staging of 1923. In order to perhaps forestall fruitless discussions of whether the play was expressionist or not, which featured prominently in the response to Denis Johnston's The Old Lady Says 'No!' (1929), the theatre advertised the 1931 revival of R.U.R. as follows: 'It is neither expressionistic nor impressionistic, but straightforward drama dealing with one of the most urgent problems of modern times.' ${ }^{\text {'13 }}$ This precaution turned out to be largely idle, since very few of the reviewers went as far as discussing the play's style or genre. The Evening Mail critic, who had described R.U.R. as an 'eerie fantasy' ('The Dublin Gate Theatre') in his review of the 1929 Gate production, re-iterated that its 'theme is of such a startling and unfamiliar nature that it cannot but arouse great interest'. He concluded, however, that 'the morbid atmosphere of the whole play and the detailed working out of impossible horrors [...] make it an unpleasant business when seen for the second time' ('A World of Robots'). Similarly, the Leader stated that R.U.R. was 'an interesting, if rather far-fetched, play' ('The Gate Theatre Reproduced'). The Irish Times critic, on the other hand, asserted that in the eight years since its first production (in English), the play had lost its topicality: 'Neither as technician nor as philosopher [...] will the claims of Karel Capek be admitted by any audience to-day.' In his view, time had revealed that 'The entire attraction of the play lay in its presentation of the embodiment of a mechanised civilisation', which makes it come across as 'little more than crude melodrama', as much as it still may be 'one of the most interesting plays now available' ('Gate Theatre').

These comments seem to be indicative of a lack of immediate relevance of R.U.R. to an early 1930s Dublin audience. This is remarkably different from early 1920s Czechoslovakia, a heavily industrialized country with a strong economy that had just gained independence, and was naturally full of optimism and belief in further progress. There, the play was viewed both as a topical warning against the dehumanization of people under the influence of modern technology, and as an image of modernity that had spiralled out of control (see Cerný 75, 83). Moreover, a number of commentators interpreted R.U.R. in relation to the experience of World War I and its use of technology for the extermination of human beings (Černý 83); Čapek himself - whose ideas were deeply influenced by the cataclysm of the Great War - stated at the time of completing the manuscript that while he was far from condemning science, 'Every technological discovery so far has been part success and part hell.' (qtd 
in Černý 82) In Ireland, only a single reviewer spoke of 'unwanted progress' in relation to R.U.R., simply arguing that 'Man, according to Karel Capek, is transforming himself into a Robot, a mechanical creature, without feeling.' (M.M.) ${ }^{14}$

R.U.R. was also interpreted in Czechoslovakia as a critique of American-style capitalism, an aspect of the play that was emphasized in the National Theatre production by the presentation of the business manager, Consul Busman, whose plump body and costume were reminiscent of a caricatured US tycoon, and of Domain and Helena as a successful American-style entrepreneur and his wife (Černý 102-103). This perspective was iterated in Dublin only by the communist reviewer for the Workers' Voice, who asserted that 'R.U.R. is a phantasy, a dream, a nightmare, visualising with terrible distinctiveness the Machine Age of Capitalism.' He went on to argue that since it was the dream of dividends that drove the company managers to create 'a machine capable of producing more than the human one could do', Čapek's work emphatically presents 'a plea for Communism' (M.D.). Nevertheless, several Czech commentators held a contrary view, pointing out that it was the collective actions and manifestoes of the Robots, together with the specific hierarchy of their organization, that clearly reflected the global rise of the workers' movement and the ascent of communism. Their interpretation was further justified by the contemporaneous polemic between Karel Čapek and the young generation of radically left-wing authors such as Karel Teige and Vítězslav Nezval, whom Čapek criticized both for their militancy and for their tendency to treat people as a mass rather than individuals (Černý 79, 83). Shortly after the première of R.U.R., Čapek wrote that the grave social issues of the present day must be resolved 'by personal engagement, rather than by comfortable doctrines or irresponsible collectivity' (qtd in Černý 84-85); elaborating on the matter, he argued in his famous 1924 essay titled 'Why I Am Not a Communist' that while communists preach about paradise on earth, their vision is based on hatred and is driven by the desire for power, and the plight of the poor is ultimately of secondary importance to them (Čapek, K. 1991). ${ }^{15}$ As much as attitudes to communism would have been prevalently negative in Ireland at the time of the Gate production of R.U.R., no commentators saw this strand in the play. This may be explained by the fact that it had been significantly de-emphasized by the English adaptors, who - as noted above - removed the allusions to the workers' movement and the communist party from the text. 


\section{Problem with Audiences}

The greatest difficulty by far of the 1931 Gate production was poor attendance. An article published in the Dublin Opinion observed that 'at the revival of "R.U.R." [...] the customers might have been counted on the feet of a centipede and some of the insect's toes would not even have been tickled' ('Stage and Screen'); the Irish Independent spoke 'about 50 souls huddled together' on the opening night (M.M.). Some reviewers attributed the low audience numbers to the highbrow reputation of the Gate; for instance, The Leader stated that 'many people seem to be afraid to venture to one of its productions on that account' ('The Gate Theatre Reproduced'). Complementing the observation, the Evening Mail critic noted that this was a revival of a difficult play produced only two years ago, while 'it is a work that most people would be content to see once' ('A World of Robots'). The frequency with which the Gate programmed revivals of recent productions was regarded as problematic by the commentator in Dublin Opinion as well, who in fact dedicated most of the article to outlining the reasons for poor patronage at Gate shows. Among these he listed the lack of publicity given by the Gate to its productions, criticizing the blandness of the showbills in particular, and the fact that two-week runs may be too long for Dublin, despite the undisputed excellence of the Gate, a theatre whose work may occasionally annoy him 'rather unnecessarily' but which he 'would go a long distance out of [his] way to preserve' ('Stage and Screen'). Quite apart from these very plausible explanations, it must be remembered that theatre had to face an increased competition from cinema at the time, since it was at the turn of the 1920s that feature films began to use sound. Indeed, as the Irish Independent review of R.U.R. testifies, poor audiences seem to have become a problem for intellectually challenging theatre in Dublin as a whole, with the drama critic complaining: 'Where are the Dublin theatregoers? I am beginning to doubt their existence.' In a response to the review, a certain J.F. heartily embraced the point, concluding that Dublin 'with its reputation for critical acumen and appreciation of talent' was 'degenerating to the level of a provincial town' (J.F.). Be that as it may, the available evidence about the 1931 R.U.R. at the Gate is conducive to agreeing with the Irish Press reviewer who asserted that this was a production 'of which any city might be proud', and that it was a shame that so few people opted to see it (D.M.). 


\section{The Insect Play}

On 24 July 1942, Hilton Edwards wrote to Brian O’Nolan, whose work as the Irish Times columnist Myles na gCopaleen he much admired:

For a long time I have wanted to produce Capek's [sic] 'Insect Play' for which I have the rights. I have not produced it because I don't like the only version available in English. I believe it is not so much a translation as an adaptation for the English theatre. I think it is cumbersome and it aims at an English colloquial quality which it misses; and which even if achieved would render the version ineffective for Ireland. [...] What about an Irish version with a tramp speaking as an Irishman would and with various insects speaking as Irish insects and not as cockneys? [...] I think very nice analogies might be made: the tramp and the Communist; the fraightfully refained $[s i c]$ upper middle class and the common people, etc., etc. [...] Would you consider making a version of this play for me? [...] I think your mind behind this, plus your name, would turn a translation into a really vital and popular Irish success. (The Collected Letters 122-23)

The play in question was Ze života hmyzu [From the Life of Insects], a dark allegorical comedy co-written by Karel Čapek with his brother Josef, who was a painter, graphic designer and a writer. The brothers actually started working on the play around 1919 (this being their third collaboration in drama), and temporarily shelved the manuscript when Karel opted for a detour to write R.U.R. (Černý 107). Ze života hmyzu premièred at the National Theatre in Brno on 3 February 1922 in a celebrated production by the young director Bohuš Stejskal. Within a mere two months, productions of the play were presented in the cities of Moravska Ostrava and Košice, and on 8 April 1922, Ze života hmyzu opened at the Prague National Theatre in a spectacular production by Karel Hugo Hilar (Černý 144), an electrifying director generally regarded as one of the most important figures in Czech theatre of the first half of the century (Figs. 6.4 and 6.5).

Despite the charge of undue pessimism raised against the authors by a number of Czech critics, and some of the audience members evidently taking offence at the play's comparison of humans to insects (Černý 108, 170-71), the play was again quickly translated into English by Paul Selver, whose version was adapted in the US by Owen Davis, and in the UK by Nigel Playfair and Clifford Bax. The American adaptation opened under the title The World We Live In at Jolson's $59^{\text {th }}$ Street Theatre in New 


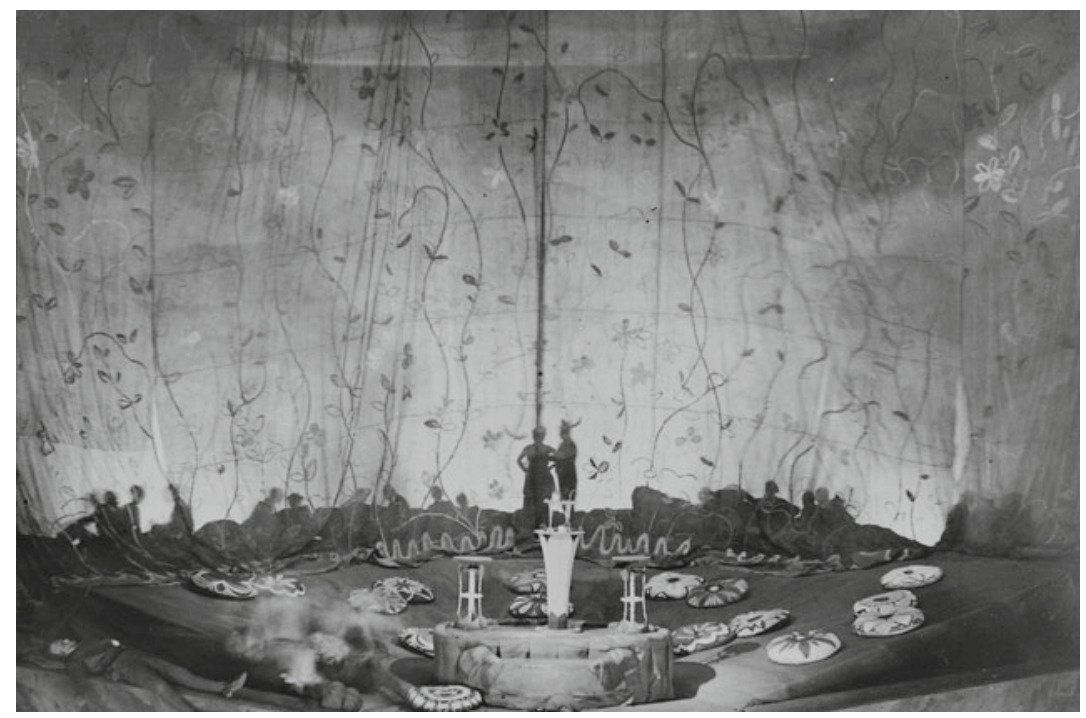

Fig. 6.4 Bratř́i Čapkové, Ze života hmyzu, Butterflies in Act I, National Theatre, Prague, 1922. Set design by Josef Čapek in collaboration with K.H. Hilar. Photograph by Karel Vána (Courtesy of the Theatre Department of the National Museum in Prague)

York on 31 October 1922, that is within three weeks of the US première of R.U.R. The production ran for 111 performances (Internet Broadway Database), and the play text was published in 1933 by Samuel French. The British version was staged as And So Ad Infinitum at Regent's Theatre in London on 5 May 1923, again on the heels of the first production of R.U.R., and stayed on for 42 performances (Wearing 225); ${ }^{16}$ the text was published by Oxford University Press the same year.

\section{TeXtual History}

As in the case of R.U.R., the Oxford edition of the 'Insect Play' which Brian O'Nolan was working from is fairly distant from the Capeks' original. However, since O'Nolan essentially rewrote the play for the Gate Theatre production, the present essay is going to reference only some of the major alterations made by Selver, or Playfair and Bax, respectively, that have influenced the Irish version in a significant way. ${ }^{17}$ 


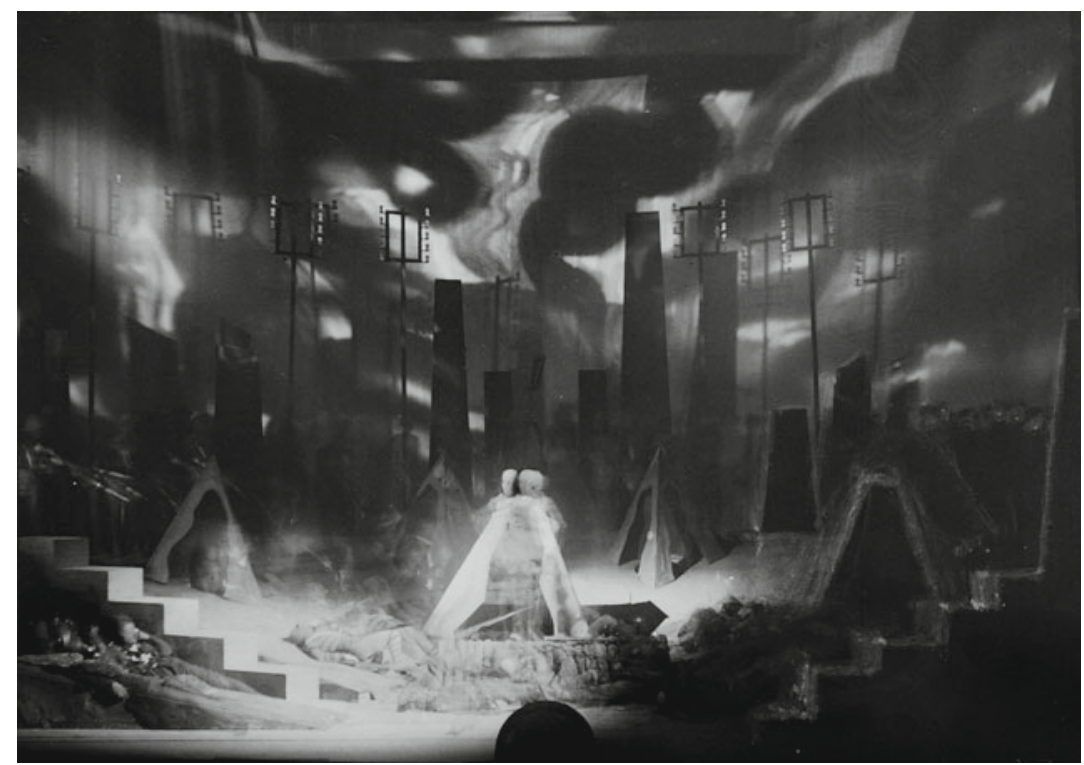

Fig. 6.5 Bratří Čapkové, Ze života hmyzu, 'Mravenika' [Ant-City] in Act III, National Theatre, Prague, 1922. Set design by Josef Čapek in collaboration with K.H. Hilar. Photograph by Karel Váňa (Courtesy of the Theatre Department of the National Museum in Prague)

Edwards secured the rights to produce Ze zivota bmyzu through the Czechoslovak consulate in Dublin relatively shortly before he commissioned the adaptation (Samek 24, 52-53). While the Gate production was to be the first professional outing of the play in Ireland, it had already been performed at the Father Mathew Hall Feis in Dublin in April 1937 (Sweney 18), for which the rights do not seem to have been solicited from the authors. Moreover, Edwards generously sanctioned an amateur production of the play by the Dublin University Players in June 1942, directed by a twenty-one-year-old Jewish refugee from Czechoslovakia, Hanuš Drechsler (H.S.K.; Quidnunc). The fact that a number of people in Dublin would have seen one or the other of these earlier amateur performances of the 'Insect Play' may have influenced the somewhat disappointing run of the Gate staging in 1943. 
Brian O'Nolan was asked to work at extremely short notice. Within three weeks of Edwards's letter, the Gate secretary Isa Hughes communicated to him the suggestion that the adaptation should be ready for the Gate's October and November season of plays at the Gaiety. This he refused, not so much due to the time constraints but because his play Faustus Kelly was to be performed at the Abbey Theatre around the same time; ${ }^{18}$ he suggested delivering the script for March next year instead (Collected Letters 123-24 nl55). The first draft of the adaptation was finished in October 1942, but rather than proceeding to finalize the script, O'Nolan sent it to Edwards and sought his view on the direction the adaptation had taken, particularly as regards what he referred to as 'naive political commentary in the last act' (Collected Letters 125-26). The director's response was generally enthusiastic. As O'Nolan included drawings of his ideas of the insects (now lost) in the margins of the typescript, Edwards sketched his own vision of the ants on the back of the letter, wearing gas masks and military helmets in a clear allusion to the world war that was going on at the time. Edwards's letter also unravels that the Capeks' butterflies of the first act were originally replaced with monkeys ('I do agree about the butterflies and always thought it unfortunate that the play opened with those impossible creatures, but monkeys are not insects - does it matter?' Collected Letters 126). Interestingly enough, O'Nolan's diary for 1943 reveals that it was his friend and occasional collaborator Niall Montgomery who wrote most of the first act featuring monkeys (Taaffe 247 n27). Remarkably, O'Nolan also consulted the physicist Erwin Schrödinger (Moore 379), who is likely to have known the Čapeks' play in German translation.

The only regret expressed by Edwards about the first draft of the adaptation was that O'Nolan had removed 'the sloppy sentimental ending' of the English version, as the director thought 'it gave a lyrical note to end on, quite beautiful and good theatre' (Collected Letters 127). However, the ending in question was largely the work of Nigel Playfair and Clifford Bax, rather than the authors of the play. The Čapeks' original ending, in which the corpse of the Tramp is discovered by a woodcutter and commented on in a matter-of-fact way only, was regarded by most reviewers of the early Czech productions as so bleak that the authors eventually supplied an alternative version in which the Tramp wakes up the next morning, realizing that his mortal agony happened only in a dream (see Čapek, K. and J. 86-92). A similar need for ending on what the Čapeks called a note of 'compromise' (Čapek, K. and J. 90) must have 
been felt by the English adaptors, who - since the alternative version was not available until the third Czech edition of the play of 1922, ${ }^{19}$ and had not been translated into English - added a sentimental closing moment that has School Children file across the stage singing 'As I went down to Shrewsbury Town', and a flower is passed on from a little girl to a baby, whose mother then lays it on the body of the Tramp (Capek, J. and K. 177).

Edwards and O'Nolan finally met - for the first time in person in January 1943, and Edwards suggested that the first act be rewritten using wasps; this O'Nolan did, and supplied the finished manuscript on 16 January 1943 (Collected Letters 127 nl65), including a sketch of a wasp on the first page. Nonetheless, due to what Robert Tracy has called 'Myles's erratic entomology' (O'Brien 85 n3), O'Nolan actually turned his wasps into bees in all but name. ${ }^{20}$ The appropriate emendations, whereby bees were no longer referred to as wasps, were made in rehearsal, and as much as the typescript that was used as the prompt book does not reflect these, they duly appeared in the published version of the play edited by Tracy.

As I have shown above, the Gate production of R.U.R. suppressed some of the author's universalist intent unwittingly due to the nature of the English adaptation of the text. The case of the Gate 'Insect Play' was different, however, in that it was intended as a local adaptation from the onset. O'Nolan shifted the place of action from an unspecified forest to Dublin's Stephen's Green. He introduced a number of new minor characters, such as the Keeper of the park, replaced the Chrysalis in Act I with a hen's Egg, and the Ichneumon Fly and its Larva with a Duck and Duckling. Characters speak with a range of strong accents: the Tramp, together with the dung Beetles, talk like Dubliners from the Northside, bees 'discuss suicide in Trinity accents' (Tracy 9-10), the Crickets speak as Corkonians, and one of the ant species is presented as Belfast unionists, as opposed to their ant enemies from the Republic. Moreover, O'Nolan worked in a hefty dose of satirical references to contemporary Ireland. ${ }^{21}$ In contrast to such ostentatious regionality, however, a number of passages in O'Nolan's version are heavily intertextual, using quotations from multiple plays by William Shakespeare or Shakespearean language, while the Capeks' original (or, for that matter, the English adaptation) features virtually no intertextual references whatsoever. Despite these major divergences from the play as originally written by the Ćapeks, Matthew Sweney is absolutely correct in asserting that O'Nolan put 
colour back into the language of Selver's translation, which was rather bloodless to start with - an issue that was further aggravated by its faulty English adaptation (Sweney passim).

\section{The Gate Production}

The Gate prompt book shows that Edwards's cuts were more extensive than had been the case with R.U.R. They mostly affected the more verbose passages, such as some of the Drone's Shakespearean speeches in Act I, and much of the discussion of Ulster unionist politics and militant propaganda by the Chief Engineer, the $2^{\text {nd }}$ Engineer and the Politician in Act III. It is indeed the act about the ants that was subjected to most extensive pruning, and also some minor restructuring, as Edwards was clearly working towards the most effective way of staging the war scenes, which shifted the emphasis somewhat from language to non-verbal action (Fig. 6.6). The relatively marginal scene featuring the Egg, the Tramp, the Duck and the Duckling in Act II was restructured along similar lines. An awareness of the audience's sensibilities is perhaps apparent in Edwards's removal of Mrs. (Dung) Beetle's line about 'some beetles' who 'do be selling their bodies to other beetles that does have a big pile like this' (O'Brien 4l), and of the comic-sounding prudishness in Mrs. Cricket referring to her pregnancy repeatedly as being 'in a certain condition' (50, 51 ) in Act II. Last but not least, many of the Tramp's lines were cut across the entire play. This decision is unfortunate in relation to the original, but appears perfectly justified given the text that O'Brien was adapting. The Tramp's role in the Čapeks' original play - regardless of arriving tipsy on the scene in Act I - is to provide a running commentary on the action: he serves as a guide for the audience, his observations are often philosophical in nature and are at times spoken in verse. He is a veteran of the Great War, a shell-shocked lost soul confined to menial jobs (Čapek, K. and J. 11-12), and was intended by the Ćapeks to embody both the authors' and the audience's perspective on the world of the insects (Černý 114, 124), serving as an insightful representative of humanity who observes the range of vices that the 'Insect Play' satirizes. In contrast, Playfair and Bax cut most of his part and turned him into a permanently drunken Cockney, a line that O'Nolan largely followed, not having access to the Czech original.

The play required what was an unusually large cast for the Gate: it features twenty-eight parts, a group of children and an unspecified 


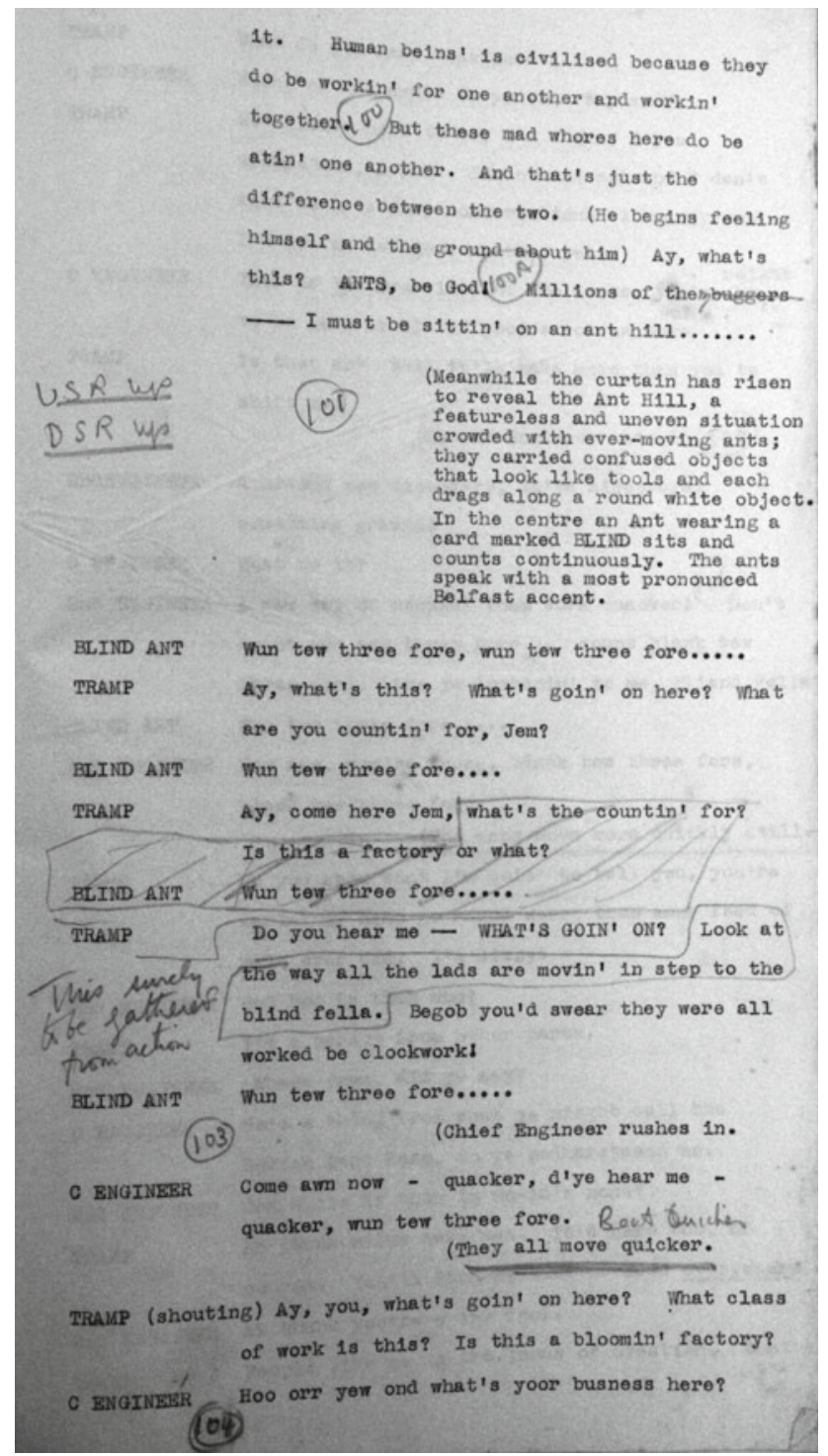

Fig. 6.6 The Brothers Čapek, The Insect Play, adapted by Myles na gCopaleen, Gate Theatre, Dublin, 1943. Prompt book. Gate Theatre Archive, Northwestern University (Copyright of the Edwards - mac Liammóir Estate) 
number of silent parts to depict the ants. Despite using twenty-one actors and nine children, the company still had to resort to some role doubling. The copies of the text of numerous parts (which are preserved in the Gate Theatre Archive) indicate that the casting was a complicated process. For instance, the parts of Mr. Cricket and the Chief Engineer are signed 'Micheál MacLiammóir'; both are heavily annotated by mac Liammóir in Irish and in English, and the latter features many doodles, at least one of which may be an idea for an insect costume (Fig. 6.7). This shows that mac Liammóir was clearly involved in rehearsals; however, in the event, neither he nor Hilton Edwards appeared in the play. The role doubling of Mr. Cricket and the Chief Engineer was retained but the parts were played by J. Winter, possibly because most roles were given to younger members of the company or its associates, with only the Gate's leading actresses Meriel Moore and Betty Chancellor appearing as Mrs. Cricket and the Queen Bee, respectively.

The title under which O'Nolan's adaptation would play likewise remained an issue until very shortly before the opening night. O'Nolan did not seem to have provided a title for his adaptation, since the folder with his typescript bears the heading 'Irish Version of Capeks' INSECT PLAY / By Myles na gCopaleen', and its first page has a question mark in place of a title. However, advance notices in the press announced the production as 'Rhapsody in Stephen's Green', an adaptation of 'Carl Capek's' or 'the brothers' Capek The Insect Play' by Myles na gCopaleen, and it is only in the programme (and presumably also on the posters) for the production that the title 'The Insect Play by the Brothers Capek. Translated and Adapted by Myles na gCopaleen' appeared first. ${ }^{22}$

The Insect Play opened at the Gaiety on 22 March 1943 and ran for one week. The lighting design was by the play's director, Hilton Edwards, set design by Molly MacEwen, and the costumes were designed by Micheál mac Liammóir. Regrettably again, none of the designs or production photographs appear to have survived. ${ }^{23}$ Thus we don't know, for instance, which of the solutions proposed by Edwards as to how the insects might be depicted was eventually adopted; Edwards wrote to O'Nolan: 'There are two ways of approaching these insects theatrically; one, to make the humans as insect-like as possible by covering up; or, two, to adapt the human figure; i.e. Mr Beetle in a shiny American cloth morning coat with tails to the ground, and bowler hat. I rather fancy the second method, but we can settle all these points later.' (Collected Letters 126) Regardless, the actors were generally lauded on their performance, 


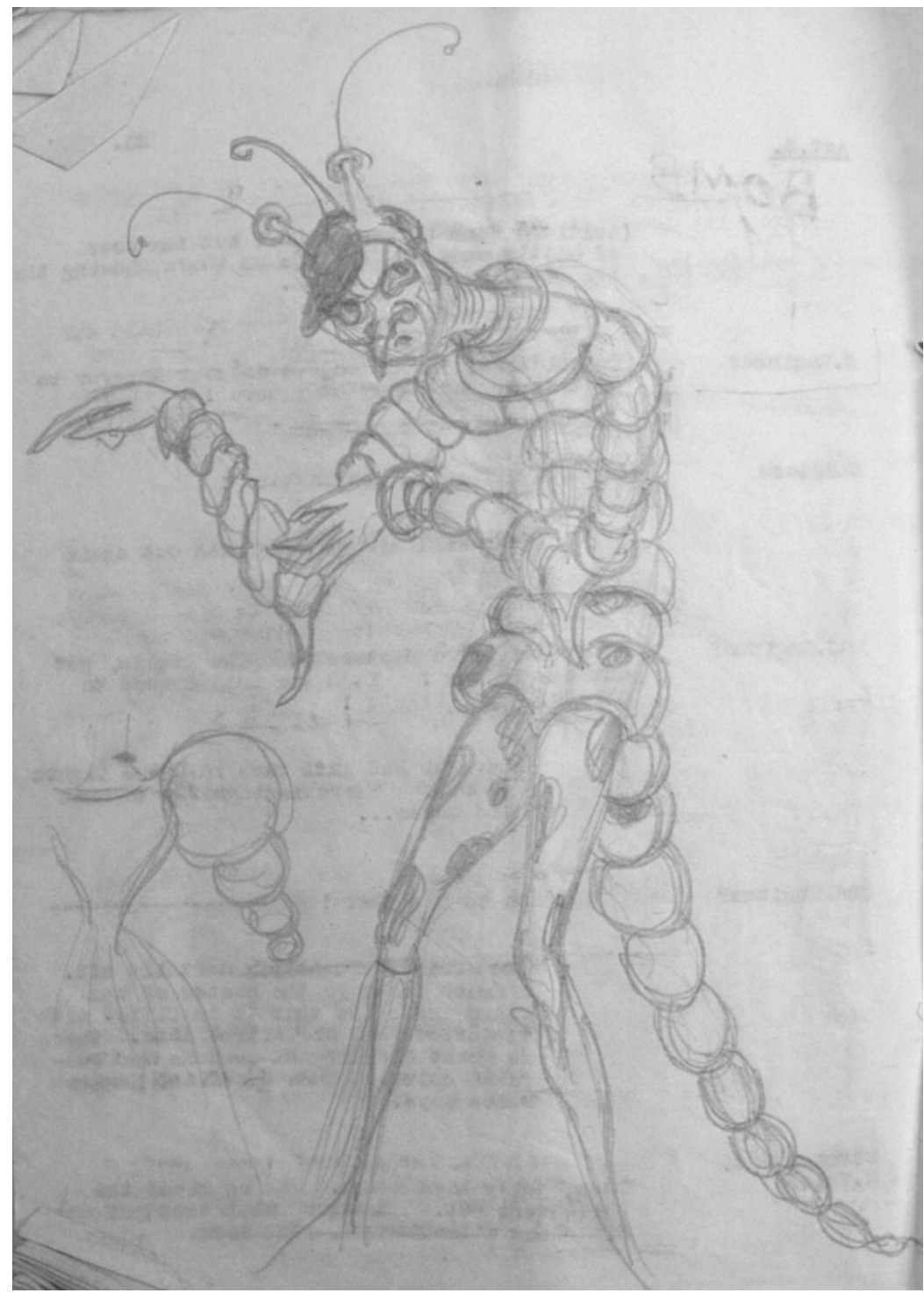

Fig. 6.7 The Brothers Čapek, The Insect Play, adapted by Myles na gCopaleen, Gate Theatre, Dublin, 1943. Insect drawing by Micheál mac Liammóir in the part of Chief Engineer. Gate Theatre Archive, Northwestern University (Copyright of the Edwards - mac Liammóir Estate) 
with Robert Hennessy singled out for praise in his role of the Tramp. A few of the reviews paid tribute to Edwards's handling of the anthill and the battle scene, and one commentator saluted the design and production qualities, concluding that this was 'a designer's and a producer's play' (D.S.). Otherwise, all reviewers focused overwhelmingly on the content of the work.

Unlike in the 1920s, to produce a play by the Čapeks during World War II was a political act, as Matthew Sweney asserts (3). Both brothers were well known internationally for their firm anti-Nazi stance in the 1930s, and while Karel died shortly before the outbreak of the war, Josef was arrested by the Gestapo in September 1939 and sent to a concentration camp, where he was ultimately to perish only days before the German capitulation. The strict neutrality in public discourse enforced by censorship during the 'Emergency' likely prevented the staging of Karel's final plays, Bilá nemoc (The White Plague, 1937) and Matka (Mother, 1938) in Ireland in English during the war due to their obvious anti-fascist message, as much as Bílá nemoc was courageously given at least an Irishlanguage production at An Taibhdhearc in 1941, translated and adapted by Buadhach Tóibín as An Sgiurrsa Bhán, directed by Walter Macken and starring Macken and Siobhán McKenna (Irish Playography; Samek 23, 52). ${ }^{24}$ Edwards and mac Liammóir were thus taking a clear stance when putting on The Insect Play in 1943, and it is with an awareness of the censorship of the press that the reviews of their production must be read.

\section{RECEPTION}

Due to the considerable disparity between the Čapeks' play as staged in Brno and Prague on the one hand, and Myles na gCopaleen's adaptation produced at the Gate on the other, the respective critical response naturally differed in a number of ways. The reviews in Czechoslovakia were overwhelmingly positive, and the authors ultimately received a prestigious national award for the play in 1923. However, commentators mostly struggled to find an appropriate interpretive framework for this unusual 'comedy', being puzzled by its uncommon and seemingly multifarious genre characteristics. Ze života hmyzu was thus variously called 'unostentatiously expressionistic', 'grotesque', a work of 'literary cubism', a 'cinematic' or 'philosophical ballet' (Černý 140, 141, 144), and perhaps most poignantly, a 'modern imitation of a medieval morality play' (Černý 167). Unorthodox as the play’s technique and structure may 
have appeared, even the most conservative of reviewers were enthusiastic about it as theatre. A likely explanation is offered by eminent Capek scholar Jiř́ Opelík, who has argued that the basic structure of the play which essentially consists of a series of one-act plays thrown together and framed by a prologue and an epilogue - was in fact adopted from a most popular form of art nouveau entertainment, the variety play (166-67), which was still widely practised in Czechoslovakia in the 1920s. The Irish commentators, on the other hand, were unanimous in the assumption that what they saw was intended as a relatively straightforward, hilarious satire on the state of contemporary Ireland. ${ }^{25}$

Where the Čapeks were chastised by their compatriots for a pessimistic outlook that seemed unsolicited in the enthusiastic atmosphere of the recently inaugurated, prosperous free state, Myles na gCopaleen was criticized for excessive mirth, vulgarity and blasphemy in Ireland during the 'Emergency'. A hostile review in the Irish Press objected to the use of what it viewed as gratuitously foul language and 'cheap jokes about motherhood'. The reviewer asserted that the Capeks would have been surprised to see their 'serious satire' used 'to burlesque the divisions in this country to make a theatrical holiday', and concluded that '[ $\mathrm{t}]$ he Capeks, lovers of their country, would have been amazed to find their translator and adaptor using their work to mock the movement for reviving a national language and to sneer at the people of Ireland, North and South' (T.W.). Similarly, the tireless chronicler of Dublin theatre, Joseph Holloway, now in his eighties, complained about the overuse of the word 'bloody' in the adaptation; he considered The Insect Play 'Stage-Irish', concluding that the dramatic efforts of Myles na gCopaleen 'are distinctly vulgar and common, and not suitable in the Gaiety, the Abbey, or the Gate' (qtd in Tracy 12). A much more positive review in the Times Pictorial also complained about labour pains being used as the subject of humour and regarded the 'bloodies' as tiresome; it concluded nonetheless that 'It is good for a people to be able to laugh at themselves; this has become a neglected art in many countries, and sometimes we take ourselves a great deal too seriously.' (Review... Times Pictorial)

The most vocal objector against the alleged immorality and crassness of Myles's adaptation was Gabriel Fallon, however. His scathing review in the Catholic newspaper The Standard provided an impulse for just the kind of gleeful battle in the press that Brian O'Nolan had relished since his student days; moreover, the fact that Fallon's review identified Myles na gCopaleen and Flann O'Brien ${ }^{26}$ as the same person (Collected 
Letters $134 \mathrm{nl} 183$ ) sent O'Nolan on a rampage. On 2 April 1943, The Standard published three texts alongside one another, all under the title 'Our Theatre Critic Attacked and Defended': 'Letter from Myles na gCopaleen', 'Letter from Member of Audience' signed 'S.M. Dunn', which had most likely been written by O'Nolan as well, ${ }^{27}$ and 'Our Theatre Critic's Reply and His Challenge to Myles na gCopaleen'. The following passage from Myles's response to Fallon is indicative of the timbre of the entire polemic:

we protest very strongly against a dirty tirade, which, under the guise of dramatic criticism, was nothing more or less than a treatise on dung. 'There will always be a distinction,' Mr. Fallon says, 'between the honest dung of the farmyard and the nasty dirt of the chicken run.' Personally I lack the latrine erudition to comment on this extraordinary statement, and I am not going to speculate on the odd researches that led your contributor to his great discovery. I am content to record my objection that his faecal reveries should be published. ('Our Theatre Critic')

As to Fallon's charge of obscenity, Myles noted that 'There is no reference to sex as such anywhere; it is true that there are male and female characters, but very few people nowadays consider that alone an indelicacy.' ('Our Theatre Critic') In closing his letter of protest, Myles raised what he called its 'main point': he accused Fallon of having tried, after the performance, to make the Director of the Catholic Boy Scouts, whose members were involved in the performance, to withdraw them from the show. This Fallon emphatically denied doing in his response. 'S.M. Dunn' also recorded his shock at the involvement of Catholic Boy Scouts in the performance of this 'low down jibe at all that we, as Catholics, hold dear', as he learnt from the programme for the play. The polemic was, in fact, preceded by an anonymous text published in The Standard on 27 March, titled 'Disgusting Performance', which concluded with a very similar passage about the involvement of Boy Scouts as listed in the programme; the language and style of this delightfully opprobrious article make it very likely to have been written by Brian O'Nolan, too. As a matter of fact, the programme (as preserved in the Gate Theatre Archive) includes no mention of Boy Scouts whatsoever. Instead, it lists the names of nine child actors, seven of whom were female, as acting 'by permission of Miss Ursula White'. Since it is unlikely that two versions of the programme for a play that ran for a mere seven performances were printed, it seems that 
O'Nolan invented the whole business and Fallon swallowed it hook, line and sinker. Incensed both by the play and the ensuing attack, The Standard critic announced that he was going to boycott the Edwards - mac Liammóir productions in the current season in protest against The Insect Play ('Our Theatre Critic'). ${ }^{28}$

The review that appeared in the May issue of The Bell picked up from O'Nolan's satirizing of Fallon's prudishness and asserted that in this regard, 'Ireland has apparently now reached the seventeenth century. In a few more years we shall have the drama where it was between 1720 and 1900 in Great Britain, i.e., in the soup. Then the Pussyfoots can joyfully say: "Well, there may be nothing in the plate. But isn't it clean?" (C.C. 157) On a more serious note - and to return to the issue of the 'Emergency' and censorship - the reviewer in The Bell described the Irish adaptation of the 'Insect Play' as 'more amusing than the Capeks, less interesting'. The reason he gave for his judgement was that since the 'idea' of the original 'has become painfully obvious now though it was fresh enough when it first came out to express post-last-war disillusion by comparing men to insects', the play calls for a distinctly 'modern, or local, re-interpretation', which Myles decided not to provide. Instead, he chose to 'tempe[r] Czech gloom with Hibernian irresponsibility' and has thus 'lost most of the point' (155-56). The wording is oblique out of necessity but still quite clear, including the objection raised against the version of the play not being 'local', that is, 'local' in the right sense of the word: what the reviewer criticized was that instead of adapting the play in reference to the current world war, be it in an international sense or by way of satirizing Ireland's stance to it, Myles opted largely for mere entertainment.

Likewise, as much as the commentator on the production in the Irish Tatler and Sketch did enjoy the humour of Myles na gCopaleen, they observed in a clear reference to World War II that however funny it may have seemed once to suggest that ants and bees managed their affairs at least as well as human beings, after the last four years that jest has lost its point. Certainly between us and the insects the laugh is no longer on our side.' A letter from a reader, signed 'L. Kiernan', protesting against the harsh review that appeared in The Irish Press (referred to above) argued that Myles's adaptation had retained a serious underlying meaning, since it showed 
what does happen when the part has convinced itself that it is the whole and in egomaniacal obsession sets itself out to dominate and to destroy all who differ from it. It is in this way that factions are begotten which destroys states and nations. The tendency to breed them is one which has cursed us all through our history and in bringing that truth so forcibly, if amusingly, before us - when the danger from them is perhaps greater than ever - the author [of the adaptation] was doing a national service. (Kiernan)

Finally, even the fine and detailed review in the Irish Times (probably by the writer Brinsley MacNamara [Tracy 11], who was a friend of O'Nolan's) that interpreted Myles's adaptation as a Swiftean satire on humanity with a local touch included a sentence that evidently referenced the war: 'There were moments when [the insects] brought us quite close to topics of the day, when we were as near to certain things as some of these things now are to Stephen's Green.' ('Gaiety Theatre') On the whole then, while it might appear that the domestication of the 'Insect Play' by Myles na gCopaleen largely deprived it of its universal appeal and turned it into an easy comedy that merely offended some of the more puritanical reviewers, enough of the Čapeks' original concept remained to allow for a broader allegorical reading that encouraged at least some of its spectators to muse about the current global cataclysm.

The Insect Play fared better with audiences than the revival of R.U.R. in 1931 and was given 'a most enthusiastic reception from a large audience' on the opening night ('Gaiety Theatre'). However, given that the cheque that was sent to O'Nolan by the Gate came with apologies for being 'a very poor reward for all the work' (Collected Letters $127 \mathrm{nl} 65$ ), and that the production was never revived, the high expectations that Hilton Edwards had had of the venture were evidently not fulfilled. The fact that his accomplished production received ample praise was likely small consolation, since superlatives used in connection with the work of the Gate's original artistic directors had become a staple feature of critical commentaries by the early 1940s.

\section{CONCLUSION}

The story behind the Čapek productions at the Gate considerably differed in that R.U.R. was staged relatively shortly after its Czech première and its ensuing global success, resulting in a well-received - albeit perhaps 
modest - staging followed by a more lavish but somewhat ill-scheduled revival, while The Insect Play was not presented until over two decades from its first appearance. The choice of R.U.R. chimed with the artistic preferences of Hilton Edwards and Micheál mac Liammóir in the early seasons of their theatre and its focus on contemporary international drama; the staging of The Insect Play, on the other hand, combined an aesthetic choice with an unequivocal political attitude. Like the original Czech productions, the Gate versions were praised for the originality and efficiency of the director's work, impressive scenography and fine acting. The reception of the Čapeks' work by Irish spectators must, importantly, be viewed in relation to the nature of the play texts that were staged by the Gate, particularly when compared with that by the original audiences in Czechoslovakia: R.U.R. was based on a faulty English adaptation of a translation that was merely passable to begin with, while The Insect Play was a relatively free 'Irish' adaptation that was made from a similarly deficient English version. The principal point of convergence in the Czech and Irish reviews consists in both plays being regarded as powerful allegories that spoke to the moment - were it newly independent, prosperous Czechoslovakia in the early 1920s or neutral Ireland in 1943, still dominated by the issue of national identity while having a world war on its doorstep. The fact that some commentators on the revived production of R.U.R. at the Gate in 1931 came to regard Karel Capek's warning against dehumanization due to the overuse of technology as too fantastic and/or bleak to be taken seriously may be viewed - together with the low audience numbers - as indicative of the ethos of proudly independent but isolationist Ireland of the day perhaps, where the experience of World War I had faded into the distance (or was actively suppressed) and where the level of industrialization was very moderate yet. The critical response to The Insect Play, on the other hand, provides a fascinating glimpse into how the uneasy proximity of World War II was felt at the time of its production, as much as the commentaries may have been dominated by prudish objections and the focus on the larger-than-life figure of the satirical columnist Myles na gCopaleen. ${ }^{29}$

\section{Notes}

1. The number of performances - which might seem relatively low - must be seen in relation to the nature of programming at continental ensemble theatres (such as the Prague National), where a number of productions 
would be running simultaneously at any given time, with new titles playing more frequently at first and eventually once or twice a month only. Moreover, the size of the theatre must be considered as well, as the Prague National seated approximately 1000 spectators at the time.

2. The Czech original of the response is reprinted in Čapek 1968, 299-301.

3. A succinct expression of the seminal role of emotions in the theatre may be found in Edwards's The Mantle of Harlequin: '[...] the theatre's function is not to appeal directly to the mind, but to the mind through the emotions. I have never yet met with a play that succeeded in its objective and made an appeal primarily to the intellect. Such a work is usually sterile in the theatre.' (123)

4. Ćapek made a whole set of revisions for the second edition of the play, which was used for subsequent Czech productions of the play and became the basis for the more recent English translations of R.U.R.

5. A typescript version of the English adaptation was also the source for the American incarnation of R.U.R., produced by the Theatre Guild at Garrick Theatre on 9 October 1922 in what was the English-language première. The Theatre Guild made numerous alterations that differ from the text that appeared from Oxford University Press in 1923 (Philmus 1320). The Theatre Guild production ran for 184 performances (Internet Broadway Database), and the text of their version was published in the US by Doubleday in the same year as the British edition. To make matters even more complicated, Philmus has shown that the text of the adaptation published by Oxford University Press does not quite correspond to the version used at St. Martin's Theatre for their production, as preserved in the papers of the Lord Chamberlain's Office at the British Library (15).

6. For instance, the name became 'Werstand' in German and the drama played as W.U.R. in consequence; likewise, in French, the name was rendered as 'Rezon'.

7. Apart from all these changes, Fabry and Hallemeier were cut altogether in the first London production (Philmus 18 and the frontispiece to the Oxford edition of the play).

8. The US producers explicitly cited this as the reason for making a similar cut in their production (see Philmus 18).

9. While it is possible that Selver was unable to find an appropriate translation of the Czech idiom, this hardly explains the extent of the deletions in the published version.

10. Unless noted otherwise, all archival materials referenced in this chapter come from the Gate Theatre Archive lodged at the McCormick Library of Special Collections at Northwestern University.

11. See Pádraig Ó Siadhail's chapter in the present volume, p. 57.

12. Interestingly, the Doubleday edition of R.U.R. (but not the Theatre Guild production) added flowers in this scene as well, although in a different 
place: Helena puts a flower in Primus's hair after she has smoothed it and tells him that he looks ridiculous; they both burst out laughing, and wake up Alquist. See Philmus $30 \mathrm{n} 42$.

13. The sentence - most likely written by Hilton Edwards - appeared in advance notices published in three Dublin papers, and partially in a fourth; see "'R.U.R." at the Gate' and the item 'The Gate Theatre' from the Evening Mail, the Evening Herald and the Irish Independent.

14. The present comparison is somewhat lacking in balance as regards the material that it is based on. This is due to the status of the respective productions, i.e. a first production of a new play by a promising author of a recently emancipated literature at the National Theatre, on the one hand, and a revival of an experimental foreign play at a relatively small theatre in a culture still preoccupied with the national on the other: the former garnered twenty-four largely extensive reviews, several of which were written by prominent intellectuals such as Otokar Fischer (for a complete list, see Črný 442-43), while reviews for the latter were only a few and mostly rather brief.

15. This essay became one of the reasons why Čapek's work was suppressed by the authorities in Czechoslovakia after the communist takeover in 1948.

16. K.H. Hilar was invited to assist with directing the play by both the New York and the London producers. As he was not given leave of absence by the National Theatre for the New York production, he eventually collaborated on the Regent's Theatre staging only (Černý 166).

17. A brief summary of the principal differences between the original and the Oxford version was provided by James Partridge, who concluded that the 'translation/adaptation is particularly poor and completely misrepresents Čapek's [sic] play' (229).

18. In the event, Faustus Kelly did not open until January 1943, two months before the opening of The Insect Play.

19. The third edition includes both endings, together with the suggestion that the director chooses between them according to his/her preference, a format that has been replicated in all subsequent Czech editions (Černý 123-26).

20. Time constraints may have been a factor here as well, since O'Nolan complained in his diary: 'They asked me to write a whole new act within the week. I promised I would do it without actually having the time for it.' (trans. from Irish and qtd in Taaffe $247 \mathrm{n} 27$ )

21. A detailed summary of O'Nolan's innovations is provided by Robert Tracy in his introduction to the published text (O'Brien 9-11). Most contemporary references are identified in Tracy's notes to the text and are discussed further in Taaffe 180-81.

22. Robert Tracy claims in his introduction to the published text that 'Rhapsody in Stephen's Green was Myles's working title' (14 $\mathrm{nl}$ ) but does 
not cite any evidence for this. On the other hand, Ruud van den Beuken has pointed out to me that 'Symphony in Green' was an early title for Denis Johnston's The Old Lady Says 'No!'; should this be more than a tenuous link, it would indicate that the working title would have more likely come from Edwards than O’Nolan.

23. The two production photos listed in the catalogue of the Gate Theatre Archive cannot be located.

24. For further details about the production, see Markus 64-68.

25. There is again a discrepancy as regards both the nature and the quantity of commentaries that are being compared here which is due to the difference in the theatrical contexts: although reviews of The Insect Play did appear in eleven periodicals in Ireland, Ze života bmyzu was regarded as the theatrical event of the season in the two cities where it was produced by their national theatres; as a result, there were ten largely extensive reviews of the Brno production and as many as twenty-seven of Hilar's production at Prague (cf. Č erný 446-48).

26. Flann O'Brien was the pen name under which O'Nolan published all of his English-language novels and a few shorter works in English.

27. Tracy has arrived at the same suspicion; see Tracy 15 n19. Ian Walsh has pointed out to me that if this is the case, O'Nolan may be playing on the word 'donn' in Irish, which is homophonous with 'Dunn' and means 'brown' - an appropriate colour given Fallon's analogy.

28. About a year later, Edwards and mac Liammóir retaliated by officially barring Fallon from their productions via a letter to the editor of The Standard (published together with Fallon's bad review of Desire under the Elms, and a brief retort to the letter, in The Standard on 16 February 1944). Ultimately, however, they all made up and Fallon contributed a comprehensive, moving tribute to Edwards and mac Liammóir's work to Peter Luke's volume about the Gate Theatre, Enter Certain Players (40-46).

29. Work on this chapter was supported by the European Regional Development Fund Project 'Creativity and Adaptability as Conditions of the Success of Europe in an Interrelated World' (No. CZ.02.1.01/0.0/0.0/16_019/0000734). I am grateful to Jiř́ Opelík for his advice on Capekiana, my friend Matthew Sweney for generously sharing a late draft of his forthcoming work on The Insect Play with me, and to the staff of the McCormick Library of Special Collections at Northwestern University for allowing me to work with the materials from the Gate Theatre Archive during the hectic time of a major cleaning project, and indeed for going out of their way to accommodate all my queries. 


\section{Works Cited}

'A World of Robots'. 1931. Review of Karel Čapek, R.U.R. at the Gate Theatre, Dublin. Evening Mail, 23 September.

Čapek, Josef, and Karel Čapek. 1961. R.U.R. and The Insect Play. Trans. Paul Selver. Adapted by Nigel Playfair (R.U.R.) and Nigel Playfair and Clifford Bax (The Insect Play). Oxford: Oxford University Press.

Čapek, Karel. 1930. R.U.R. Trans. Paul Selver. Adapted by Nigel Playfair. London: Humphrey Milford/ Oxford University Press. Prompt copy, Dublin Gate Theatre. Gate Theatre Archive, Northwestern University. B999rX.

Čapek, Karel. 1968. Divadelníkem proti své vilii: recenze, stati, kresby, fotografie [Theatre Maker Against His Will: Reviews, Essays, Drawings, Photographs]. Ed. Miroslav Halík. Praha: Orbis.

Čapek, Karel. 1991. 'Proč nejsem komunistou' [Why I Am Not a Communist] (1924). In Karel Čapek, O vécech obecných ćili Zóon Polítikon, 84-95. Praha: Melantrich.

Čapek, Karel. 2018. R.U.R. Praha: Městská knihovna. Ebook.

Čapek, Karel, and Josef Čapek. 2018. Ze života bmyzu [From the Life of Insects]. Praha: Městská knihovna. Ebook.

C.C. 1943. 'Theatre'. The Bell 6.2 (May): 155-61.

Černý, František. 2000. Premiéry bratrí Čapki [The Brothers Čapek First Productions]. Praha: Hynek.

'Degree for Amateur Actor'. 1931. Irish Independent, 11 December.

'Disgusting Performance'. 1943. Standard, 27 March.

D.M. 1931. 'R.U.R. Revived at the Gate. Review of Karel Čapek, R.U.R. at the Gate Theatre, Dublin'. Irish Press, 23 September.

D.S. 1943. “"The Insect Play”: An Enjoyable Satire'. Review of The Brothers Čapek, The Insect Play, adapted by Myles na gCopaleeen at the Gate Theatre, Dublin. Irish Independent, 23 March.

'Dublin Gate Theatre - R.U.R.' 1931. Programme for the Performance. Gate Theatre Archive, Northwestern University.

Edwards, Hilton. 1958. The Mantle of Harlequin. Dublin: Progress House.

Fitz-Simon, Christopher. 2002. The Boys: A Biography of Micheál MacLiammóir and Hilton Edwards. $2^{\text {nd }}$ edn. Dublin: New Island Books.

'Gaiety Theatre. "The Insect Play"'. 1943. Irish Times, 23 March.

'Gate Theatre. Revival of "R.U.R."'. 1931. Irish Times, 23 September.

H.S.K. 1942. 'Capek [sic] Play in The Peacock'. Irish Independent, 2 June.

Internet Broadway Database. https://www.ibdb.com. Accessed 28 September 2019.

Irish Playography. http://www.irishplayography.com. Accessed 28 September 2019.

J.F. 1931. 'Dublin Theatregoers'. Irish Independent, n.d.

Kiernan, L. 1943. 'Readers' Views: “The Insect Play”'. Irish Press, 25 March. 
Luke, Peter, ed. 1978. Enter Certain Players. Edwards-Mac Liammoir and the Gate 1928-1978. Dublin: Dolmen Press.

Markus, Radvan. 2018. 'Bílá nemoc a Osudy dobrého vojáka Švejka: česká literatura v irskojazyčných inscenacích' [ The White Plague and The Good Soldier Švejk: Czech Literature in Irish-language Stage Versions]. Divadelni revue 29.3: 63-77.

M.D. 1931. “R.U.R.” at the Gate Theatre'. Workers' Voice, 10 October.

M.M. 1931. "Where Are the Theatre-Goers? "R.U.R." at the Gate'. Review of Karel Čapek, R.U.R. at the Gate Theatre, Dublin. Irish Independent, 23 September.

Moore, Walter. 1989. Schrödinger: Life and Thought. Cambridge: Cambridge University Press.

O’Brien, Flann (Myles na gCopaleen). 1994. Rhapsody in Stephen's Green: The Insect Play. Dublin: Lilliput Press.

Opelík, Jiř́i. 1980. Josef Capek. Praha: Melantrich.

'Our Theatre Critic Attacked and Defended'. 1943. Standard, 2 April.

Partridge, James. 2000. 'Karel Čapek 1890-1938'. In Encyclopedia of Literary Translation into English, Vol. 1. Ed. Olive Classe, 227-29. Chicago and London: Fitzroy Dearborn.

Philmus, Robert M. 2001. 'Matters of Translation: Karel Čapek and Paul Selver'. Science Fiction Studies 28.1: 7-32.

Quidnunc. 1942. 'An Irishman's Diary'. Irish Times, 30 May.

Review of the Brothers Čapek, The Insect Play, adapted by Myles na gCopaleeen at the Gate Theatre, Dublin. 1943. Irish Tatler and Sketch, March.

Review of the Brothers Capek, The Insect Play, adapted by Myles na gCopaleeen at the Gate Theatre, Dublin. 1943. Times Pictorial, 26 March.

“"R.U.R.” at the Gate. Dublin Production of Kapek's [sic] Notable Play'. 1931. Irish Press, 22 September.

Samek, Daniel. 2009. Cesko-irské kulturni styky v prvni polovinè 20. stoleti / CzechIrish Cultural Relations, 1900-1950. Trans. Ondřej Pilný. Praha: Centre for Irish Studies, Charles University.

'Stage and Screen'. 1931. Dublin Opinion, October, 268.

'Suicide of Actor'. 1931. Irish Press, 30 October.

Sweney, Matthew. 2018. 'The Insect Play: Rhapsody in Stephen's Green by Myles na gCopaleen and Ze života hmyzu by the Brothers Capek'. Unpublished essay.

Taaffe, Carol. 2008. Ireland Through the Looking-Glass: Flann O'Brien, Myles na gCopaleen and Irish Cultural Debate. Cork: Cork University Press.

The Collected Letters of Flann O'Brien. 2018. Ed. Maebh Long. Victoria, TX: Dalkey Archive Press.

'The Dublin Gate Theatre Presents a Revival of R.U.R.'. 1931. Promotion leaflet. Gate Theatre Archive, Northwestern University.

'The Gate Theatre'. 1931. Evening Herald, 19 September.

'The Gate Theatre'. 1931. Evening Mail, 18 September.

'The Gate Theatre'. 1931. Irish Independent, 19 September. 
'The Gate Theatre Reproduced “R.U.R.”'. 1931. Leader, 3 October.

Tracy, Robert. 1994. 'Introduction'. In O'Brien, Flann (Myles na gCopaleen). 1994. Rhapsody in Stephen's Green: The Insect Play, 1-17. Dublin: Lilliput Press.

T.W. 1943. "“The Insect Play” at the Gaiety'. Irish Press, 23 March.

Vernon, Frank. 1924. The Twentieth-Century Theatre. London: Harrap.

Wearing, J.P. 2014. The London Stage 1920-1929: A Calendar of Productions, Performers, and Personnel. $2^{\text {nd }}$ edn. Lanham: Rowman \& Littlefield.

Open Access This chapter is licensed under the terms of the Creative Commons Attribution 4.0 International License (http://creativecommons.org/licenses/ by $/ 4.0 /)$, which permits use, sharing, adaptation, distribution and reproduction in any medium or format, as long as you give appropriate credit to the original author(s) and the source, provide a link to the Creative Commons license and indicate if changes were made.

The images or other third party material in this chapter are included in the chapter's Creative Commons license, unless indicated otherwise in a credit line to the material. If material is not included in the chapter's Creative Commons license and your intended use is not permitted by statutory regulation or exceeds the permitted use, you will need to obtain permission directly from the copyright holder.

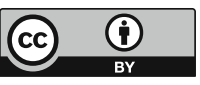

